\title{
TÜRK HUKUKUNDA YABANCILARIN OTURMA VE ÇALIŞMA HAKKI
}

\author{
Doç.Dr. Bilgin TIRYAKIOĞLU*
}

GíRiş

Bu makalede yabancıların oturma ve çalışma haklan, Türk yabancılar hukuku ve gerçek kişilerle sinırlı olarak ele alınmaktadır. Türkiye'nin konuyla ilgili olarak taraf olduğu milletlerarasıs sözleşmeler çalışmanın kapsamı dışında bırakılmıştır.

Yabancılarin Türkiye'de oturma hakkından bahsedebilmek için öncelikle yabancınm ülkeye geçerli ve usulüne uygun bir giriş yapması gerekmektedir. Bu nedenle, oturma hakkının ön koşulu olarak ülkeye giriş hakkı bu çalışma içinde yer almıştır.

Yabancıların Türkiye'de çalışma haklan, çalışma hakkının genel şartlari çerçevesinde irdelenmiş ve özellikle çalışma vizesinin bu genel şartlar arasında yer alıp almadığı, Türk pozitif hukuku bakımından çalışma vizesinin zorunlu olup olmadığı sorunu tartışılmıştır. Genel şartlar dışında, yabancıların çalışma hakkına iliş̧in olarak kanunlarda öngörülen sınırlamalar her bir çalışma alanı ve meslek bakımından tek tek ele alınmayıp, Türk (pozitif) hukukunun genel karakteri ortaya konmuştur.

I- Türk Hukukunda Kabul Edilen Sistem

\section{A) Kural}

Türk hukukunda siyasî haklar bir tarafa burakılacak olursa yabancıların haklan bakımından vatandaşlarla eşitlik esası kabul edilmiştir. Anayasanın 10. maddesi, yabancıların hukukî. durumunu tesbitte eşitlik (ve genellik) ilkesini belirleyici niteliktedir:

* Ankara Oniversitesi Hukuk Fakiltesi Devletler Özel Hukuku Anabilim Dalı Ögretim Üyesi 
"Herkes, dil, ark, renk, cinsiyet, siyasi düşünce, felsefi inanc, din, mezhep ve benzeri sebeplerle ayırnm gözetilmeksizin kanun önünde eşittir.

Hiç bir kişiye, aileye, zümreye veya sınıfa imtiyaz tanınamaz.

Devlet organlart ve idare makamlan bütün işlemlerinde kanun önünde eşitlik ilkesine uygun olarak hareket etmek zorundadrlar".

Yabancı ve vatandaşın eşitliğini teyit eden diğer bir hüküm de Türk Medeni Kanununda yer almaktadir. Anılan Kanunun 8. maddesi hükmünü hatırlamakta yarar vardır: "Her şahıs, medeni haklardan istifade eder. Binaenaleyh kanun dairesinde haklara ve borçlara ehil olmakta herkes muisavidir".

\section{B) Sinırlama}

Anayasanın 10, maddesindeki eşitlik ilkesinin sınırlan 16. maddede belirtilmiştir. Buna göre,

"Temel hak ve hürriyetler, yabanctlar için, milletlerarası hukuka uygun olarak kanunla sınırlanabilir".

Bu Anayasa ilkelerinden ortaya çkmaktadır ki, kamu hakları alanında yabancılar ve vatandaşların eşitliği kural, sınırlamalar ise istisnadır. Sınırlamalar, istisna olması nedeniyle dar yorumlanmak gerekir. Yani yabancilann karnu haklari ancak milletlerarası hukuka uygun olarak sınırlanabilir ve bu sınırlamaların da mutlaka kanunla yapılması gerekir.

Kanunda getirilen sinurlamalar genel nitelikte olup, bütün yabancı kişiler bakımından aynı kısıtlayıcı sonuçları meydana getirmektedir ${ }^{1}$.

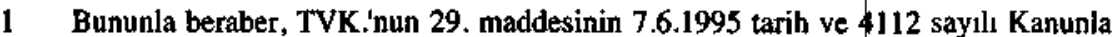
dełisstirilmesinden sonra, doğumla Tük vatandaşlığını kazanmış olup da sonradan Bakanlar Kunulundan çıkma izni almak suretiyle yabancı statüsünił kazanan kişiler ve bunların kanunî mirasçları bakımından istisnaî bir durum ortaya çıkmış̧ır. Kanunun 29. maddesindeki bu deł̧işiklik neticesinde, söz konusu kişiler, diğer yabancılardan farkh olarak Tütkiye Cumhuriyetinin milli güvenliği ve kamu düzenine ilişkin hükümler saklı kalmak kaydiyla iilkede ikamet, seyahat, çalışma, miras, taşınır ve taşınmaz mal iktisabı ve ferağı gibi konularda Türk Vatandaşlarına tanınan haklardan aynen yararlanmaya devam edeceklerdir. Sinırlamalann genel nitelikte olmasına ilişkin kuralın diǧger bir istisnası, 25 Eylül 1981 tarih ve 2527 sayılı "Türk Soylu Yabancilann Türkiye'de Meslek ve San'atlarinı Serbestçe Yapabilmelerine, Kamu, Özel Kunuluş veya tşyerlerinde Çalıştınlabilmelerine hiş̧in Kanun"dur (RG.29 Eylül 1981-17473). 


\section{II- Türk Hukukunda Yabancıların Kamu Haklan}

Kamu haklan Anayasa'da "kişinin haklan ve ödevleri" ve "sosyal ve ekonomik haklar ve ödevler" olmak üzere iki bölümde düzenlenmiştir.

Anayasa, bu hak ve ödevlere ilişsin hüküm getirirken, bunlann sahiplerini belirlemek bakımından, "herkes", "hiç kimse" gibi genel ifadeler kullanmıştır. Aynca 16. maddedeki esas da göz önünde tutulunca, Anayasada, kamu haklarinı, yabancıları da kapsayan bir teminata bağlama yoluna gidildiği sonucuna varılmaktadır ${ }^{2}$.

\section{OTURMA HAKKI}

\section{I- Oturma Hakkının Ön Koşulu Olarak Ülkeye Giriş}

Yabancılarnn bir ülkede oturma hakkının ön koșulu, o ülkeye geçerli ve usulïne uygun giriş yapmalarıdır. Hemen belirtmek gerekir ki, yabancının Türkiye'ye usulüne uygun giriş yapmı̧̣ olması, ona dogurdan doğruya oturma hakkını sağlamaz.

Devlet, yabancının ülkeye girişini dïzenleme yetkisine sahiptir. Türkiye'ye girişi, asıl, Pasaport Kanunu düzenlemektedir. Bu düzenleme çerçevesinde, Türkiye'ye giremeyebilecek olanlar sadece yabancılardır. Vatandaşlar, "devletin vatandaşı illkeye kabul ödevi" nedeniyle Türkiye'ye her zaman girebilirler. Türkiye'ye giriş bakımından, Pasaport Kanunundaki vatandaşlara ilişkin hüküimler vatandaşlı̆̆ın isbatı ile ilgili bulunmaktadır.

Milletlerarası hukukta "devletin vatandaşı kabul ödevi" nedeniyle vatandaşın ülkeye girişi koşullara bağlanamaz. Buna karşıllı, milletlerarası hukuk, yabanciyı ülkeye kabul etme zorunluğu yüklemez. Ancak, milletlerarası hukukta hiçbir yabancıyı ülkeye kabul etmeme şeklinde bir ilke de yoktur ${ }^{3}$.

Türkiye'ye geçerli ve usulüne uygun "giriş yapabilmek" için gerekli şartlar şunlardır:

-Türkiye'ye giriş, "Giriş Kapılan"ndan olur. Giriş kapılarını Bakanlar Kurulu tayin eder.

2 ÇELIKEL, A.: Türk Yabancilar Hukuku, B.6, Istanbul 1998, s.71; TEKINALP, G.: Türk Yabancilar Hukuku, B.6, Istanbul 1998, s.35.

3 TEKINALP, age., s.37. 
Pasaport Kanunu, m.1/1: "Türk vatandaşları ve yabancılar İçişleri Bakanlığının teklifi üzerine Bakanlar Kurulunca tayin olunan yolcu giriş kapılarından Türkiye'ye girip, çıkabilirler".

Pasaport Kanunu (değişik) m.2/I: "Gümriik ve diğer işlemlerin yapılabilmesi için polis makamlannca giriş veya çıkış işlemlerinin bitirilmesi şarttır".

-Pasaport ve vesika gösterme mecbüriyeti.

Pasaport Kanununun 2. maddesinin ilk fikrasina göre, Türk vatandaşları ile yabancılar Türkiye'ye girebilmek ve Türkiye'den çıkabilmek için yolcu giriş ve çııı̧ kapısındaki polis makamlarına usulüne uygun ve muteber pasaport ve pasaport yerine geçerli bir vesika ibraz etmeye mecburdurlar".

Pasaport K.nun 4/I. mađdesine göre pasaportsuz, vesikasız veya usulüne uygun veya muteber olmayan pasaport veya vesikalarla Türkiye sınırlarına gelen yabancılar geri çevriliirlers.

4 Pasaport Kanununun 3. maddesine göre, "Pasaportsuz veya vesikasız, usulìne uygun veya muteber olmayan pasaport veya vesikalarla Türkiye sinırlarına gelerek Türk vatandaşlığını iddia edenler:

(a) Türkiye Cumuhuriyeti nüfus hüviyet ciizdanlarını veya hüviyet varakalarını ibraz ettikleri ve bunlann kendilerine ait bulunduğu tahakkuk eylediği takdirde;

"(b) Nüfus hïviyet varakasından başka vesika veya delil gösterenler ise, bu vesika veya delillerin kıymeti polisçe takdir edilerek Türk vatandaşı olduklanna kanaat getirilmesi halinde Türkiye'ye kabul olunurlar.

"Yukaridaki (b) fikrasinda bahis mevzuu olan kimseler vatandałlıklar en seri vasıta ile usulü veçhile sabit oluncaya kadar icap ederse en yakın idarę merkezine gönderilerek mahalli mülkiye amirinin gösterecegi yerde oturabilirler.

Türk vatandaşlı̆̆ sabit olmayanlar geri çevrilirler".

5 Pasaport Kanununda bu kuralın istisnaları muhtelif maddelerde yer almuştır:

-Pasaport veya belgelerini yolda kaybedenler (Pasaport Kanunu m. 4/II): Bunlardan pasaport veya vesikalarını yolda kaybettiklerini iddia edenlerin łçişleri Bakanlığınca yapılacak soruşturma sonuna kadar, jcabederse, en yakın idare merkezine gönderilerek haklarında verilecek karara göre işlem yaptimak üzere, mahalli müllkiye amirinin gösterece ği yerde oturabilmek kaydıyla kabulleri caizdir.

-Göçmenler (Pasaport K., m.4/III): Hükômetin müsaadesi ile gelen göçmenler ellerinde Türk konsolusluklarının ve göçmen sevki için yabancı memieketlere hükômetçe gönderilen memur veya heyetleri tarafından verilmis bir vesika bulunmak şartıyla pasaportsuz da olsalar Türkiye'ye kabul olunurlar.

-Mülteciler (Pasaport K., m. 4/IV): Umumiyetle mültecilerin ve iskan hakkındaki mevzuat dişında olarak yurt tutmak maksadiyla gelen yabançların, Pasaportlart olsun olmasın Türkiye'ye kabulleri İçişleri Bakanlığının karanna bağlıdır.

- Vatansızlar (Tâbiiyetsizler) (Pasaport K., m.26/I) :"Aşağıda yazılı şahıslara Türkiye için giriş vizesi verilmesi İçişleri Bakanlığının müsaadesine bağlıdır:

"A) Tabiiyetsizler (Haymatlozlar);

"B) Nansen pasaportu hamilleri;

"C) Seyahat belgeleri (afidavit, lesepase ve saire) ve benzeri vesika hamilleri". 
-Türkiye'ye girmesi yasak olan kişilerden olmamak.

Bu durumda olanlar, yabancllard $\mathbf{r}^{6}$.

-Giriş vizesi almak.

Yabancrlar, ülkeye geçerli giriş yapabilmek için, giriş vizesi almak zorundadırlar. Bu zorunluluk Pasaport K.nun 25. maddesin$\mathrm{de}^{7}$ belirtilmiştir:

Türk hukukunda ilke, yabancuların Türkiye'ye giriş için vize mecburiyetine tâbi olduklarıdır. Bu ilkenin istisnalan vardır ${ }^{8}$.

6 Pasaport K., m. 8, "Türkiye'ye girmeleri memnu kimseler"i sôyle sıralamaktadır:

-Serseriler ve dilenciler;

- Deliler ve bulaşıci hastalığ olanlar;

-Tirkiye Cumhuriyetinin taraf oldưg müucrimlerin iadesine mitteallik anlaşma veya anlaşmalarla iadeye esas qlarak kabul edilen suçlardan birinden sankk veya hükümltu bulunanlar;

-Túrkjye'den sınır dışı edilmiş olup da, geri dönmesine izin verilmemiş olanlar;

-Türkiye Cumhuriyetinin emniyetini (güvenliğini) ve genel dúzenini bozmak niyetiyle veya bozmak isteyenlere ve bozanlara iştirak veya yardım etmek maksadıyla geldikleri sezilenler;

-Fahişeler ve kadınları fuhuşa sevkederek geçinmeyi meslek edinenlerle beyaz kadin ticareti yapanlar ve her nevi kaçakçlar;

-Türkiye'de kalacaklarını beyan ettikleri müddetçe yaşamalanna ve tekrar gitmelerine yetişecek paraları bulunmayıp Türkiye'de kendilerini himaye edecek kimseleri bulundugunu veya Türkiye'de yabancılara karşı men'edilmemiş işlerden birini tutacaklann ispat edemeyenler.

7 "Bu kanunda derpiş edilen istisnalar dışında yabancıların Türkiye sınırlanndan içeriye girebilmek jçin yetkilti Türk makamlarnndan vize almalari mecburidir. Vizesiz olarak Túrkiye sınurlanna gelenlerin memlekete kabulü ilgili emniyet makamlarının misaadesine bałłlıdır.

"Türk vatandaşlan Türkiye'ye gelmek için vize almak mecburiyetine tâbi deł̧ildirler".

8 1. Tứrkiye'ye yalnız bir giriş için muteber olmak üzere verilen "yabancılara mahsus" damgalı pasaportlar giriş vizesine tâbi degildir (Pasaport K., m.5/II, m.18/II).

2. Başka ïlkelere gitmekte olan; veya, sırf turizm veya gezi maksadiyla tek başına veya grup halinde seyahat eden yabanclar, emniyet makamlarından izin alarak, geldikleri hava ve deniz limanlannin bulunduğu sehirlere, vizesiz olarak, inip gezebilirler, oralarda geceleyebilírler (Pasaport K., m.6/).

3. Hava yoluyla Türkiye'den, Türk hava limanından ayrilmaya lüızum kalmayacak sekilde transit geçecek yabancular için vize mecburiyeti yoktur (Pasaport K., m.6/ II).

4. Uçaktan uçał̆a aktarma yapacak olan yolculann aktarmayı bekleme süresi içersinde vizesiz olarak hava alanıun şehrine çlkmalanna izin verilebilir (Pasaport $\mathbf{K}$., m.6/III).

5. T.C. Hükametinin kendikeriyle vize kolaylıklarına ilişkin anlaşma yaptığ rin vatandaşları da vize mecburiyetinden, anlaşma hükümleri uyannca yararlanabilirler (Pasaport K., m.10).

6. Pasaport Kanununun 10. maddesi uyarınca, Hükûmetin yetkisini kullanarak, tek taraflı işlem ile haklarında vize mecburiyetini kalđırdığı devletlerin tebaası da, Türkiye'ye vizesiz giris yapma imkanundan yararlanacaklardır. 
Vize mecburiyeti, yabancılar için vardır. Türk vatandaşları, vize mecburiyetine tâbi tutulmamıştır. Esasen, vatandaşı ülkeye kabul ödevi dolayısıyla, aksi yönde bir tutum garip olur ve etkisi tartışma konusu yapilırdı.

Türkiye'ye giriş vizesi, Türkiye sınılarından içeriye muteber surette giriş yapmayı sağlar; böylece, yabancı, Türkiye'de, hukuken, yabancilarnn tâbi olduğu statüye uygun olarak bulunmak yetkisini kazanmaktadır.

Olağan olarak giriş vizesi, yabancının Türkiye'de "ikamet etmesine" yeterli degildir; bu husus, Yabancıların Türkiye'de İkamet ve Seyahatleri Hakkında Kanun (YISHK) hükümleri başta olmak üzere, ilgili çeşitli mevzuata tâbidir (karş. Pasaport Kanunu, m. 25).

Türkiye'ye geçerli ve usulüne uygun bir giriş yapmak, yabancıya Türkiye'de oturma hakkını otomatikman sağlamaz. Bununla beraber, Yabancilarn İkamet ve Seyahatleri Hakkında Kanunda yapılan dełişiklik, bazı durumlarda ikamet tezkeresi olan yabanciya vizesiz giriş imkânı sağlamaktadır.

Pasaport Kanunu, hükûmete, yabanciların Türkiye'ye girişiyle ilgili olarak, yukanda belirtilen şartlarda değişiklik yapabilmesi için birtakım istisnâ̂ tedbirler almasını mümkün kılan yetkiler tanımıştır ${ }^{10}$.

94361 sayıl ve 14.5.1998 Tarihli "Yabanclların Türkiye'de İamet ve Seyahatleri Hakkında Kanunun Bir Maddesinde Deģişiklik Yapılmasına Dair Kanun". Söz konusu Kanun'un birinci maddesi ile getirilen değişiklik şöyledir: "İkamet tezkeresi sahibi yabancılardan, geri dönmek üzere Türkiye dışına giden ve ikamet tezkeresinin süreși bitmeden dönenler için vize aranmaz. Bu Yabancıların, sınır kapılanında geçerli ikamet tezkerelerini ibraz etmeleri Türkiye'ye girişleri için yeterlidir.

10 Bu yetkiler şunlardır:

-İstisnaî pasaport ve vize kolaylıkları (Pasaport K. m. 10)

"Huikûmet yabancı devletlerle pasapor ibrazı ve vize alma mecburiyetinin kaldırlması veya vizelerin harçtan muaf tutulması da dahil olmak tzere pasaport ve vize işlerinde kolaylıklar göstermesine miiteallik karşılıklı anlaşmalar yapmaya ve lïzum göreceğ hallerde bazı devletler tebaalan için vize mecburiyetini tek taraflı olarak kaldırmaya yetkilidir".

-Savaşta ve fevkalâde hallerde (Pasaport Kanunu, m.11)

"Bakanlar Kurulu, harb halinde veya diger olağanüstif hallerde memleketin bir bö]gesine veya umumuna şamil olmak lizere bätün veya bazı yabancilar için Pasaport ve vizeye müteallik kayit ve șartlar koyabilit".

-Mukabele bilmisil (Pasaport Kanunu, m. 9)

"Bakanlar Kurulu, hakimiyetleri veya idareleri alında bulunan memleketlere Türk vatandaşlarınun girmelerini kayıt ve şartlara tâbi kılan veya men'eden devletler tebaaları hakkında münasip göruilecek kayıt ve şartlari koymaya veya bunların memleke. te girmelerini men'etmeye ve bu kanunda derpiş edilen bilcümle mali hükümlere nispetle Tưrk vatandaşları hakkında daha az müsait hüikümler tatbik eden devletler tebalan hakkında mukabele bilmisil tedbirleri almaya yetkilidir". 


\section{II- Yabancılarnn Oturma Hakkına Ilişkin Genel Hükümler}

Yabancilar, Türkiye'ye geçerli ve usulüne uygun şekilde giriş yaptıklan takdirde, oturma hakkının ön koşulunu gerçekleştirmiş olurlar. Yabancılann Türkiye'de oturma hakkı iki şekilde kayıt ve şart altına alınabilir.

Yabancilar, kanunlarla tayin olunan kayıt ve sartlar dairesinde Türkiye'de oturma hakkına sahip olurlar. Bu konudaki genel hüküm YISHK.'nun 1. maddesinde yer almaktadır". Diğer kanunlarda da bu yönde hükümler vardır' ${ }^{12}$.

Yabancıların oturma hakkı konusunda aynca idarî işlemlerle de dỉzenleme yapılabilir. Bu idarî işlemleri yapma yetkisi Bakanlar Kurulu ve İçişleri Bakanlığına tanınmıştır.

YISHK.'nun 2. maddesi, Bakanlar Kuruluna, yabancllarin oturma hakkı ile ilgili olarak, hem genel nitelikte bir yetki, hem de karşı işlem yapma yetkisi tanımıştır:

"Yabanclarin girmekten ve ikametten kanunla men'edilmiş olduklan yerlerden başka, memleketin muayyen mintukalarndda münferit veya toplu bir halde ikamet veya seyahatieri Bakanlar Kurulu karart ile men'edilebilir.

"Bakanlar Kurulu bu gibi tedbirlerin mukabele-i bilmisil olmak üzere muayyen devlet tebaalarına tatbikine de kasar vermeye yetkilidir".

İçişleri Bakanlığı ise, mülteciler bakımından YİSHK.'nun 17. maddesinde ${ }^{13}$, sınırdışı etme konusunda YISHK.'nun 19. vd. maddeleri ile TVK.'nun 33. ve 35. maddelerinde yetkili kılınmıştır.

\section{III- Íkamet Tezkeresi}

\section{A) Kural}

Türkiye'de bir aydan fazla kalacak yabancilann kural olarak ikamet tezkeresi almaları gerekir. Bu husus YISSHK.'nun 3. maddesinin ilk fikrasında belirtilmiştir:

11 Türkiye'ye girmesi kanunlaria memnu bulunmayan ve Pasaport Kanununun hit. kilmlerine uygun sekilde gelen yabancilar, kanunlarla tayin olunan kayit ve sartlar dairesinde Tuirkje'de ikamet ve seyahat etmek hakkını haizdirler".

12 Ömeğin, Köy Kanunu, m.88; Askeri Yasak Bölgeler ve Güvenlik Bölgeleri Hakkında Kanun, $\mathrm{m} .7$ ve 9.

13 "Siyasi sebeplerle Türkiye'ye sı ğınan yabancılar ancak Içişleri Bakanlığınca müssade olunacak yerlerde ikamet edebilirler". 
"Türkiye'de bir aydan fazla kalacak yabancilar bu müddet bitmeden ikamet tezkeresi almak için gerekli beyannameyi doldurmak üzere yetkili emniyet makamlarına bizzat veya bilvasıta müracaat etmekle ödevlidirler. Bu beyanname hiçbir harç ve resme tâbi değildir".

B) İkamet Tezkeresinin Süresi ve Şekli

İkamet tezkerelerinin süresi hakkında genel kural YİSHK., m.8'de yer almaktadır:

"Yabancılara verilecek ikamet müsaadesinin süresi, mevzuatın ve yabanc1 devletlerle akdedilmiş bulunan anlaşmaların hükümleri dairesinde ve mümkün mertebe, müracaat sahibinin talebi nazan itibara alınmak suretiyle tesbit olunur".

İkamet tezkerelerinin süresini en fazla iki yıl ile sınırlayan YİSHK.'nun 9. maddesi, 4360 sayıl1 ve 14.5.1998 tarihli Kanun ${ }^{14}$ ile değiştirilerek, ikamet tezkerelerinin süresi 5 yıla çıkarılmıştır. Karşıllkkılık ilkesi uyarınca bu süre, Dişişleri Bakanlığının görư̧̧ü alınmak suretiyle, Iç̧işleri Bakanlığı tarafından, daha uzun veya daha kısa olarak tespit edilebilir. Süresi biten ikamet tezkeresi üzerinde en fazla dört defa uzatma işlemi yapılabilir.

İkamet tezkeresinde belirtilen sürenin sona ermesine rağmen, ikamet tezkeresi yenilenmemiş ise, yabancinın bir ay içinde Türkiye'yi terketmesi gerekir; terketmemiş ise YiSHK., m. 19'daki müeyyide uygulanır, yani yabancı sınır dışı edilir.

İkamet tezkerelerinin şahsî ve müşterek olmak üzere iki türü vardır. Aslolan ikamet tezkerelerinin şahsî olmasıdır (YÍSHK., m.9/III). İ̧ sahibi olan yabancılar, mutlaka "şahsî ikamet tezkeresi" almak mecburiyetindedirler (YISHK., m.9/III). Bununla beraber, kan, koca ve bunların onsekiz yaşını doldurmamış çocuklarına, ya hepsi için, yahut çocukların baba ve analarının refakat hanesine kaydı suretiyle, müşterek ikamet tezkeresi verilebilir (YISSHK., m.9/III).

C) Hükümleri

Yabancıların hüviyetlerini ispat mecburiyeti: Yabancllar, hüviyet varakasını, ikamet tezkerelerini veya pasaport ve kontrol fişlerini her istenişte polis veya jandarmaya göstermeye mecburdurlar YISHK., m.18).

14 Yabancıların Türkiye'de Íkamet ve Seyahatleri Hakkında Kanonun İki Maddesinde Def̧işiklik Yapılmasına ve Bu Kanuna Bir. Ek Madde Eklenmesine Dair Kanun (RG. 16.5.1998-23344). 
Ikamet tezkerelerinin yenilenmesi: Türkiye'de ikamet tezkerelerini yenilemek veya süresini uzatmak isteyen yabancılar bu tezkerelerde yazılı sürenin sona ermesinden itibaren on beş gün içinde 3 . maddede yazılı makamlara bizzat veya bilvasita müracaat ederek 9. madde hükümleri çerçevesinde yenisini almaya veya süresini uzattrrmaya yüküimlüdürler (YISHK., m.10/I). Tezkerelerde yazılı sürenin sona ermesinden önce de müracaat yapılabilir (YISHK., $\mathrm{m}$. 10/II).

İkamet tezkeresinin kaybolmast: İkamet tezkerelerini kaybedenler derhal ilgili makama müracaatla yenisini almaya mecburdurlar. Bunlara kaybettikleri ikamet tezkerelerinin mïddeti süresince muteber olmak üzere yeniden ikamet tezkeresi verilir (YISHK., m.11).

Geçici olarak Türkiye'den ayrlma: YISHK'nun (4361 sayılı Kanunla değişik) 13. maddesine göre, ikamet tezkeresi sahibi yabancılardan, geri dönmek ïzere Türkiye dışına giden ve ikamet tezkeresinin süresi bitmeden dönenler için vize aranmaz. Bu yabanc1lann, sınır kapılarında geçerli ikamet tezkerelerini ibraz etmeleri Türkiye'ye girişleri için yeterlidir.

D) Usul

-Başvuru ve beyanname verme zorunlugu

Tïkiye'de bir aydan fazla kalacak yabancilar, bu müddet bitmeden ikamet tezkeresi almak için gerekli beyannameyi doldurmak üzere yetkili emniyet makamlarına bizzat veya bilvasıta müracaat etmekle ödevlidirler(YISSHK., m.3/I).

Başvuru makamlart, Y'SHK., m.3/I uyarınca, yetkili emniyet makamlaridır.

Is tutmak maksadiyla Türkiye'ye gelen yabanctlar, YISHK., m.3/I uyarinca, geldikleri tarihten itibaren bir ay zarfinda ve her halde çalışmaya başlamazdan evvel ikamet tezkeresi almış bulunmalıdırlar. Ancak YISHK., m.3/II'de bu kurala istisna getirilmiştir:

"Konferans, konser vermek gibi külttirel faaliyetlerde bulunmak üzere turneye çukmış olup da Türkiye'ye gelen yabancılar, bu faaliyetleri bir aydan fazla sürmemek şartıyla bu kayıttan müstesnadır".

IV- Íkamet Tezkeresi İsteminin Reddedileceği Haller

YISHK., m.7'de ikamet tezkeresi isteminin hangi hallerde reddedileceği sayılmıştır's ${ }^{15}$ Istemde bulunduğu halde, ikamet tezkeresi 
verilmeyen kişi YISSHK., m.3'de belirtilen veya anlaşmalarla öngörülen süre bittikten sonra ülkeyi terk etmelidir. Ülkeyi terketmeyen yabancı sınır dışı edilir.

\section{V- İstisnaî Durumlar}

Bazı hallerde, ilgili yabancı, Türkiye'de kalıș zamanı bir ayı geçmekle beraber, ikamet tezkeresi almakla mükellef tutulmamaktadır. YÍSHK.'nun 4, 5 ve 6. maddelerinde özel durumlar düzenlenmiștir.

-YISHK.'nun 5. maddesinde belirtilen "Turist" damgah giriş vizesi almış münferit pasaport taşıyan yabancllar, vizelerinde ikamet bakımından tahdidi tazammun eden bir şerh mevcut değilse, dört ay müddetle ikamet tezkeresi almakla mükellef değildir.

-YİSHK.'nun 4. maddesi uyarınca müşsterek pasaportla seyahat maksadıyla veya gösteri, kongre, konferans ve sergilere gelenler ile ziyaret ve tedaviye gelenler iki ay, Türkiye'de ikamet tezkeresi almadan bulunabilirler. Iki aylık süre, gerektiginde, vilayetler tarafindan iki ay daha uzatılabilir.

-Triptik belgeleriyle, milletlerarası turizm ve otomobil birlig̈inin gümrüklerden giriş karneleriyle gelen yabancı gezginler dört ay süre için ikamet tezkeresi almakla mükellef deģildir (YISHK., m.6).

$\mathrm{Bu}$ özel işlemler dışında, yabancı devletlerin Türkiye'de görevli personeli ve aileleri ${ }^{16}$ ile yabanc1 devletlerin görevli personelinin müstahdemleri ${ }^{17}$ de ikamet tezkeresi alma yükümlïlügüunden muaf tutulmuşlardır.

15 Aşağıda sayılan yabancıların ikamet tezkeresi istemleri reddolunur:

- Sırf iş tutmak için gelecek san'at ve meslek erbabı olup da tutacă̆ı iş kanunjar gereğince Türk vatandaşlarına hasredilmiş bulunanlar;

-Tirk kanun veya örf ve adetleriyle yahut siyasi icabatla telif edilmeyecek durumda olan veya faaliyette bulunanlar;

-Titrkiye'de kalmak istedił̆i muliddet zarfında yaşamak için maddi imkânlanı meşru bir şekilde temin edemeyeceğgi sabit olanlar;

-Tírkiye'ye girmesi memnu olup da her nasılsa girmiş bulunanlar;

-Türkiye'de oturduğu müddetçe huzur ve asayişi ihlal edenler.

16 YİSHK., m.28/I: "Yabanc1 devletlerin Türkiye'de görevli bulunan personelinden siyasî temsilcilik memurlan, konsolosluk resmî memurları ve bunların aileleti efradi ikamet tezkeresi almakla yülklimlü değildir".

17 YISHK., m.28/IV: "Siyasi temsilciliklerde yanlarında oturmak suretiyle hizmetlerinde bulunan yabancılara mïtekabiliyet §artıyla Dışişleri Bakanilığının delaletiyle Emniyet Genel Müdürliügúunce birer hüviyet varakası verilir ve bonlar 3'ïncii maddede yazilı ikamet tezkeresini alamazlar". 
Nihayet, iki veya çok taraflı anlaşmalar ile belirli süreler için ikamet tezkeresi alma şartı kaldırılabilmektedir.

\section{VI- Bildirim ve Ihbar Yükümlülüikleri}

İkamet tezkeresi almı̧ olan yabancıların, ikametgâhlarında, medenî hallerinde ve ikamet sebebinde ${ }^{18}$ meydana gelen değişiklikleri bildirme yükümlülükleri vardur. Aynca Türkiye'de çalışmaya başlayan yabancılar ile onlan çalıştıran kişi ve kurumların da bildirim ve ihbar yükümlülükleri vardır.

YİSHK.'nun 14. maddesi, ikametgâhdaki değişikliğin bildirimini düzenlemektedir. Bu madde uyarınca, "Tkamet tezkeresi taşıyan yabancılar ikametgâhlarinı deģiştirdiklerinde keyfiyeti $\mathbf{4 8}$ saat zarfinda gerek çıktiklan, gerek naklettikleri yerdeki polis veya jandarma karakoluna bizzat veya bilvasıta veya taahhütliu mektupla haber vermeye mecburdurlar".

"Otel, pansiyon gibi yerlerde yabancılar için ihbar mecburiyeti bu yerlerin sahibi, müsteciri veya idarecilerine aittir".

Medeni hal değişiklikleri de YİSHK., m.12 uyarnnca bildirilecektir: "Yabancilar medeni hallerinde husule gelecek değişiklikleri bu deł̧işikliğin husulünden itibaren 15 gün içinde bulundukları mıntıka zabıta makamlarına imzalı bir beyanname ile haber vermeye ve keyfiyeti ellerindeki ikamet tezkerelerine kaydettirmeye mecburdurlar".

Türkiye'de çalışmaya başlayan yabancıların bildirim yükümlülükleri YISHK., m.15/II'de düzenlenmiştir: "Türkiye'de serbest olarak veya memur, müstahdem ve işçi sıfatıyla çalışacak yabancılar, keyfiyeti işe başladıklarından itibaren ve en çok 15 gün zarfında ikamet ettileri yerin polis veya jandarma karakoluna bizzat veya bilvasita haber vermeye ve ikamet tezkerelerine kaydettirmeye mecburdurlar".

Yanlarında yabancı çalıștıranlar ise YISHK., m.16'da belirtilen yükümlülüğü yerine getireceklerdir. Söz konusu hükme göre: "Evlerinde veya idareleri altunda bulunan yerlerde bir yabancıyı herhangi bir sıfatla çaIıştıran hakikj veya hükmi her şahıs o yabancının adını ve soyadını, tâbiiyetini, mesle đ̌ini, taşıdığı ikamet tezkeresinin tarih ve sayısını, ikametgah süresini ve gördüğ̈i işle aldığı maaş ve ücret miktannı gösterir imzalı bir beyannameyi yabancının işe başlamasını takip eden en çok 15 gün içinde en yakın polis veya jandarma karakoluna vermeye mecburdur".

18 YISHK, m.10/son: "Medeni hallerinde ve Türkiyede ikamet sebeplerinde de gisikiklik olmayan yabancılar yenileme muamelesi için tiçüncti maddede yazıll beyannameyi vermezler"; hïkmïn mefhumu muhalifinden, Tüirjye'deki ikamet sebeplerinde degişiklik olan yabancilann, YISHK., m.3'de belirtilen beyannameyi (m.3'e kıyasen 1 ay içinde) doldurmak tizere yetkili emniyet makamlanna bizzat veya bilvasıta bassvurmak zorunda bulundukları sonucu ortaya çikmaktadır. 


\section{VII- İstisnaî Tedbirler}

YISHK.'nun 30. maddesinin ilk fikrası, Bakanlar Kuruluna kanunda yazılı süreleri deģiştirme ${ }^{19}$, ikinci fikrasında ise karşı işlem yapma yetkisini ${ }^{20}$ tamımıştır.

\section{VШI- Yabanciların Türkiye'yi Terke Davet Edilmesi ve Sınır Dı̧̧ı Edilmesi}

Sınır dışı etme, yabancilarn Türkiye'de oturma haklarını ilgilendiren bir tedbirdir. Vatandaşı ülkeye kabul ödevinin iç hukuka intikal eden sonucu olarak (AY. m.23/son), "Vatandaş sınır dışı edilemez ve yurda girme hakkından yoksun birakılamaz".

Sınır dışı etme işleminin Türk hukukunda muhtelif kanunlarda düzenlendiği görülmektedir.

YİSHK.'da "sınır dışı" etme ile ilgili hükümler, Türk hukukunda "sınır dı̧ıı etme"yi asıl dízenleyen kanunî hükümlerdir. Sınır dışı etmeye dair Pasaport Kanunu ${ }^{21}$ ve TVK.ndaki ${ }^{22}$ mevcut hüküm-

19 YISHK., m.30/I:"Bu kanunun 3'üncü, 4'ünca, 5'inci, 6'nc1, 10'uncu, 12'nci, 14'üncü,

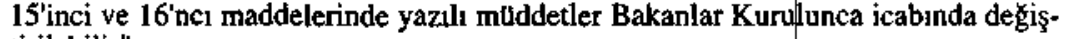
tirilebilir".

20 YİSHK., m.30/II: "Bakanlar kurułu (I. fikrada belirtilen sürelèrle ilgili) bu değişik. likleri, mitekabiliyet veya mukabelei bilmisil sebebiyle, muayyen devletler tebaasina inhisar ettirebilir". Ancak burada, mütekabiliyet (karşıllkli işlem) gereksiz ve yanlış kullanılmıştır: Karşılıklı işlem bir kanunî şartır ve "a priori" ve soyut nitelik arz eder; oysa, maddede "a posteriori" bir tavirla ilgili işlem (tasarruf) ve somut içerikli karar niteliği taşıyan bir tasarruf söz konusudur. Bu nedenle burada belirtilen "tedbirler", hep "(mukabele bilmisil) karşı işlem tedbiri" kabilindendir.

21 -Pasaport Kanunun 8. maddesinde Türkiye'ye girmeleri yasak kimseler sayılmıştır. Bunlar hakkında, eğer girmiş iseler, ne yapılacağına dair hüküm yoktur. Bu takdirde, iki ihtimal söz konusudur: Îlk ihtimal Pasaport K.'nun 34. maddesinin kıyasen uygulanmastdır. Söz konusu maddeye göre, "Türkiye Cumhuriyeti sınırlarından her nasılsa pasaportsuz olarak girebilmiş olan vatandaşlar ve yabancilar 250 liradan 1250 liraya kadar ağtr para veya 1 aydan 6 aya kadar hapis cezasıyla veya her ikisiyle cezalandirliur.

"Bu gibilerden yabancı olanlar cezalarını çektikıen sonra sınır dışı edilirler".

Ancak 34. maddenin cezaî karakteri göz önüne alınırsa kıyasen uygulama mümküin göruinmemektedir. Íkinci ihtimal, bu kişilerin YISHK, m.19'un kapsamuna dahil edilmesidir. Son çözllm, bize dahà uygun gelmektedir.

22 Türk Vatanđaşlığı Kanununda sınır dişı edilme, (TVK., m.24'e göre) haklarındaki vatandaşlı̆̆a alımma kararı iptal edilen kişiler için düzenlenmiştir (TVK.m.33/III): "Vatandaşlı̆ı iptal edilenterin mallarının tasfiyesi ile kendilentinin sınır dışı edilmeleri lüzumlu görüldiłgü takdirde bu husus iptal kararında belirtilir. Bu gibiler en geç bir yıl içinde Tükiye'deki mallann tasfiye ederek, ikametgah ve iş merkezlerini yurt dışına nakil ile memleketi terk etmek zorundadır. Aksi halde, malları hazinece satılarak bedelleri nam ve hesaplanna milli bir bankaya yatınlır ve kendileri de sınır dı̧̧ı edilir. Bu kişiler iptal kararı aleyhine Danıştaya başvurdukları takdirde, mallann tasfiyesi ve sınır dışı edilme işlemleri dava sonuna bırakılır".

Burada yetkili makam, usul, sınır dışı işleminin (kararının) etkileri gibi hususlarda YISHK.' nun 24 vd, maddeleri klyasen uygulanır. 
ler, sınır dışı etme tedbirinin uygulanacağı özel halleri tespit etmekte ve bu özel haller bakımından anilan tedbire eklenebilecek diğer tedbir veya hükümleri göstermekle yetinmektedir. Buna karşılık, Pasaport Kanunu ve TVK., sınır dişı etmenin usulüne ve sonuçlarına ilişkin kapsamlı bir dïzenleme içermemektedir.

O halde, diğer mevzuattaki sınır dışı etme ile ilgili hükümlerin uygulanması bakımından mevcut boşluklar, konuyu genel olarak düzenleyen kanun olarak, YISSHK.'nun hükümleri uyarınca doldurulacaktır.

Türkiye'yi terke davet ve gerektiğinde sınır dışı edilecek yabancılar YISSHK.'nun 19 vd. maddelerinde belirlenmiştir ${ }^{23}$.

Sınır dıșt etmeye yetkili makam, YISSHK., m.21// uyarınca İçişleri Bakanlığıdır ${ }^{24}$.

23 -Muzur kişiler (YISHK., m.19): "İçişleri Bakanlıł̆ınca memlekette kalması, umumi güvenliǧe, siyasi ve idari icaplara aykın sayılan yabancilar verilecek muayyen müddet zarfinda Türkiye'den çlkmaya davet olunur. Bu mỉddetin sonunda Türkiye'yi terk etmeyenler sınır dıșı edilebilir".

-Pasaportlarin yenilemeyenler (YISHK., m.20): "Usulüne uygun olarak Türkiye sınurlarna girmis olduklan halde pasaportlarnı zayi etmis olan veya pasaportlannın hükmü kaldınlmıs bulunan yabancılar, kendilerine ilgili makamlarca resmen ihtar vuku buldư̛̆u tarihten itibaren 15 gün içinde pasaport veya tâbiiyet ilmúhaberi almaya mecburdurlar". Bu mecburiyetin icabın yerine getirmeyen yabancıların tâbi tutulacağ 1 muieyyidenin ne oldugu sorusunun cevabı kanumun ne bu maddesinde, ne de dił̌er maddelerinde yazılıdır. Ancak, üzerinde durduğumuz 20. maddenin sistematik yorumu, bu múeyyidenin "sınır dısı edilme" olacałıłı göstermektedir: Zira söz konusu madde, "yabancilann Türkiye'yi terke davet veya sınır dişı edilmeleri halleri" başlı̆̆ altında yer alan maddelerden biridir.

- Cingeneler ve göcebeler (YISHK., m.21/III): "Tấbiiyetsiz-veya yabancı devlet tebaası olan çingenelerin ve Türk kültürỉne bağlı olmayan yabancı göçebelerin sintr dısı edilmelerine Içişleri Bakanlığı salahiyetlidir".

24 YISHK., m.21/H: "Içişleri Bakanlığ1, lïzum görecę̆gi sınır ve sahil illerine memleketin umumi güvenlik ve nizam noktasından derhal çukartlması lazım gelen yabancılar istizan etmeden sınır dışı etme yetkisini verebilir. Bu iller, bu yetkiye gôre işlem yaptıkları takdirde keyfiyeti mucip sebepleriyle birlikte İçişleri Bakanlığına bildirmeye mecburdurlar".

YISHK., m.21/1II: "Tâbiiyetsiz veya yabancı devlet tebaası olan çingenelerin ve Türk kültüirine bağlı olmayan yäbancı göçebelerin sınır dışı edilmelerine İçişleri Bakanlığı salahiyetlidir".

Bu son fikrada, kapsamına giren haller bakımından kanun, açıkça İçişleri Bakanlığnı zikrettiłyinden (ve tespit ettił̧inden), vilayetlere devredilebilen yetkinin kapsamına bu haller girmez (karş. m.21//I ve ayrıca Bakanlığın yetkisini, II. fikradan sonra bilhassa zikreden III. fikra). 
Sınır dışı etme işlemi, yabancının ülkede oturma hakkını etkilediği kadar, Türkiye'ye yeniden girişleri bakımından da bazı sonuçlar dogurmaktadır's.

\section{Çalışma Hakkı}

\section{I- Genel Olarak}

Millî hukuklarda bazı çalışma alanlarının yabancılara tamamen yasaklandığ, bazılarının izin şartına bağlandığı; bazı devletlerde ise birtakım işlerin yabancılara karşılıklı işlem şartına tâbi tutularak açıldı̆̆ı görüilmektedir.

Çalışma alanlarının, kamu güvenliği, millî savunma, kamu sağliğı ve kamu düzeninin asgarî gereklerine uygun düşen yasaklamalar ve kısıtlamalar dışında, yabancılara açık tutulduğı gözlenmektedir.

$\mathrm{Ne}$ var ki, bazı ulkelerde kamu yararı kavramına da zaman zaman başvurularak vatandaşlarnn kayınlması amacına dönük sınırlandưmalara hâlâ yer verildiği görülmektedir: Vatandaşı, çalışma alanında yabancinin rekabetine karşı koruma ${ }^{26}$.

Bunlara ek olarak, kamu hizmetinin görülmesinde, özellikle kamu idaresine katılma, devlet yetkisinin kullanılmasına iştirak veya kamu hizmetinin bir kamu görevi suretinde ifası çerçevesinde, bu gibi işlerde çalışma hakkının vatandaşlara hasredilmesi yolundaki uygulama yaygınlığını korumaktadır.

\section{II- Türk Hukukunda Yabancıların Çalışma Hakkı}

Calışma hakkı, kişiye tanınması gereken temel haklardan olmas1 sebebiyle kamu haklarn arasında yer almaktadır ${ }^{27}$. Türk hukukunda, başta Anayasa olmak üzere, muhtelif kanunlarda yabancılarn çalışma hakkı konusundaki kurallar belirlenmiştir.

25 YISHK., m. 22/I uyarınca, Türkiye'den sınır dışı edilenler Içişleri Bakanlıł̆ııın hususi müsaadesi alınmadıkça Türkiye'ye dönemezler; bunlardan ağır hapis cezasını müstelzim bir cürümden dolayı Türkiye'de mahküm olmuş ye cezası çektirilerek sınır dış edilmiş olanlar bir daha Türkiye'ye giremezler; ancak. Içişleri Bakanlığının müsaadesiyle (durmadan) transit geçmeleri caizdir.

26 Özellikle ekonomik bunalım dönemlerinde, isssizlik tehlikesi ve yabancıyla rekabette kaybeden vatandaşlarn meydana getirdiłi sosyal ve ekonomik problemlerin, toplum menfaati kadar, devlet menfaati bakımından da bu tür olumsuz düzenlemelere başvurmayı haklı gösteren bir durum olarak kabul edildiği gerçeği vardır. 
Anayasa'nın 48. maddesi, çalışma hakkını yabançlar için de teminata bağlamıştır:

"Herkes, dilediği alanda çalışma ve sözleşme hürriyetine sahiptir. Ozel teşebbüsler kurmak serbesttir.

"Devlet, özel teşebbüslerin milli ekonominin gereklerine ve sosyal amaçlara uygun yürümesini, güvenlik ve kararlılık içinde çalışmalarını sağlayacak tedbirleri alır".

Anayasa'nın 16. maddesindeki temel hak ve hürriyetlerin, yabancılar için, milletlerarası hukuka uygun olarak kanunla sinırlanabileceği kuralı çalışma hakkı bakımından da geçerlidir.

Yabancılarin çalıșma hakkı ile ilgili yukandaki anayasal ilkeler dişında, genel ilkeler Medeni Kanunda ve YISHK.'da yer almaktadir. Medeni Kanunun 8. maddesi yabanciların özel hukuk alanının tỉmünde olduğu gibi, çalışma hakkını da etkileyecek biçimde geçerliği olan, eşitlik ilkesini ortaya koymaktadır:

"Her şahıs, medeni haklardan istifade eder. Binaenaleyh kanun dairesinde haklara ve borçlara ehil olmakta herkes mlisavidir".

YISHK.'nun 15, maddesinin ilk fikrası, münhasıran, yabanc1ların çalışma haklar ile ilgili olarak genel ilkeyi belirlemektedir: bilirler".

"Yabancllar Türkiye'de ancak kanunun kendilerine men'etmediği işleri tuta-

Yukarıdaki hükümler çerçevesinde, Türk hukukunun, yabancllann çalışma hakkına ilişkin sistemini ana hatlanyla şöyle ortaya koyabiliriz: Yabancular, Türkiye'de kanunen kèndilerine kapanmus işler dışında her türlü işi yapabilirler.

III- Genel Şartlar

Yabancıların Türkiye'de çalışma hakkından bahsedebilmek için genel olarak ve öncelikle iki koşulun varlığı gerekir. Yukarıda "oturma hakkı" ile ilgili kısımda ayrıntılı olarak açiklanan bu koşullardan ilki, Türkiye'ye usulüne uygun ve geçerli surette giriş yapmak; ikincisi ise ikamet tezkeresi almaktır. Su halde, Türkiye'ye usulïine uygun ve geçerli surette giriş yapan bir yabancı, yine kanunî hüküimlere riyatle ikamet tezkeresini aldıktan sonra, Türkiye'de çalışabilir; ancak tutacağı iş kanunen yabancılara yasaklänmamış işlerden olmak gerekir. 
Bu nedenle, Türk kanunlarında ve genel olarak da Anayasa m.16'nın çizdiği sınırlar çerçevesinde, yabancılara yasaklanan çalışma alanlarının ne olduğunun ortaya konması büyük önem kazanmaktadir.

\section{IV-Çalışma Vizesi}

Yukarıda belirtilen genel şartlar arasına bir de "çalışma vizesi" alma şartının eklenmesinin hukukumuz açısından uygun olmadığ düşüncesindeyiz.

Gerçekten, çalışma izni (veya çalışma vizesi) karşılaştırmalı hukuk açısından gözlendiği üzere iki şekilde düzenlenebilmektedir:

-Ya ön izin şeklinde, ülkeye girmeden önce (ülke dışında) alınır ki, bu durumda ÇALIŞMA VIZESİ söz konusudur.

-Veya, ülkeye girdikten sonra (ülke içinde) yetkili mahallî makamlardan alını ki, bu durumda ÇALIŞMA IZNİ sộz konusudur.

Türk hukukunda Pasaport Kanununda olsun, YiSHK.'da olsun veyahut herhangi bir kanunda olsun, ülkeye -çalışmak üzere gelen veya ülkede çalışmaya sonradan karar veren yabancının- mutlaka ön izin suretinde, çalışma.vizesi alacağını bildiren bir hüküm yer almamaktadır. Hattâ, ülkeye girdikten sonra, çalışmaya başlamadan önce, herhangi bir makamdan izin alınması zorunluğuna dahi yer verilmemiş olduğu bir gerçektir. Bu durumun istisnası Türkiye'nin taraf olduğu milletlerarası anlaşmalardır ${ }^{28}$.

Türk hukukunda, doktrinde, yabancıların çalışma vizesi almaları gerektigyi genel kabul görmekte ve bu gereklilik YÍSHK. ve Pasaport Kanununun bazı hükümlerine dayandırılmaktadır ${ }^{29}$. YISHK.'nun "İkamet Tezkeresinin Reddolunacağı Haller" başlı̆̆ını taşıyan 7. maddesinin $(\mathrm{A})^{30}$ ve $(\mathrm{C})^{31}$ bentleri ile aymı Kanunun "İ̧

28 TEKINALP, age., s. 116.

29 ÇELIKEL, çalışma vizesi alma zorunlugunu, Pasaport Kanunu, m.8, YİSHK., m. 7/ E, m.15/1r'de yer alan húkümlere dayandırmaktadır: ÇELlKEL, age., s.112-113; OKÇUN ise vize alma zorunlulựunun iç hukuktaki dayanağııın Pasaport Kanunu. m. 4/son hükmü oldư̆u görüşündedir: ÖKÇÜN, A.G.: Yabancıların Türkiye'de Çalışma Hürriyeti, Ankara 1962, s.104-105; aynı yönde bkz. TEKłNALP, age., s.116.

30 Söz konusu bende göre, "Surf is tutmak için gelecek sanat ve meslek erbabı olup da tutacağı is, kanunlar geregince Türk vatandaşlarına hasredilmiş bulunan" yabancılara ikamet tezkeresi verilmez.

31 Bu hüküm uyannca "Türkiye'de kalmak istediği mủddet zarfinda yaşamak için maddj imkanlan meşru bir şekilde temin edemiyeceği sabit olan"yabancılara ikamet tezkeresi verilmez. 
Tutan Yabancılanı Mükellefiyeti" başlığını taşıyan 15. maddesinin . II. fikrasındaki" hükümlerinin yerine getirilmesi babında bir "çalışma vizesi" alınması mecburiyeti yoktur. YISHK.'nun 7. maddesi, açıkça, ikamet tezkeresinin reddolunacağı hallere ilişkindir ${ }^{33} ; 15$. maddesi ise, bir ihbar ödevinden söz etmektedir, ancak izne ilişkin herhangi bir kayıt içermemektedir ${ }^{34}$. İhbarı degerlendirecek yetkili makamlar, eğer yabancının YISHK., m.15/I'e ters düşen bir duruma dahil olduğunu saptarlarsa, gerekli müeyyideyi uygularlar; ve hattâ yabancıyı çalışmaktan men'edebilirler. Ama, bu izin değil, yabancomn sonradan tespit edilen kanunsuz durumunun bertaraf edilmesi zımninda, izin kurumunun tersi olan tedbir mahiyetinde bir tasarruftur.

Pasaport Kanununun 4. maddesi, Türkiye'ye girişe ilişkin birtakım istisnaî durumlan hükme baglamaktadır; anılan maddenin IV.fukrası ${ }^{33}$ ön izin (çalışma vizesi) konusunda kural çıkartmaya elvermez. Kaldı ki, anılan fikradaki "yurt tutma", İskan Kanununun dïzenleme kapsamı dışında "Türkiye'ye yerleşme" niyetiyle gelen kişilerin, bu niyetlerinin kuvveden fiile çıkmasının bağlandığı izin şartına iliş̧in olup, başka bir amaca aittir. "(Daimi) yerleşme" ile "çalışma", farklı hususlan deyimleyen kavramlardır ${ }^{36}$.

"Ön izin"in, Türk pozitif hukukunda gerekli görüldüğüi iddiasını doğrulayabilecek tek ihtimal kalmaktadır. Türkiye'ye girmesi yasak olan kimseleri sayan Pasaport Kanununun 8. maddesinin yedinci bendi hükmünün uygulanması çerçevesinde, bazı hallerde, Türkiye'ye giriş vizesi için başvuran yabancılar, kendilerinden istenilen bazı bilgileri vermek durumundadırlar. Bu bilgileri verirken Türkiye'ye sırf iş tutmak amaciyla gittiğini beyan edenlerin Pasa-

32 "Türkjye'de serbest olarak veya memur, milistahdem ve isçi sıfatıyla çalısacak yabancilar, keyfiyeti işe başladiklanndan itibaren ve en çok 15 gün zarfinda ikamet ettikleri yerin polis veya jandarma karakoluna bizzat veya bilvasıta haber vermeye ve ikamet tezkerelerine kaydettimeye mecburdurlar".

33 7. maddeniń (A) bendine göre, ikamet tezkeresi verilirken, kişinin Türklere hasredilmiş meslek ve san'atlardan birisini tutmak için ülkeye gelip gelmediği esasen araştınlmaktadır. İkamet tezkeresini alan kişi ayn bir çalışma vizesi almadan Türklere tahsis edilmemiş bir işte çalışma hakkına sahiptir: GOGER, E. : Yabancılar Hukuku, B.3, Ankara 1979, s.80.

34 GÖER'e göre: "-ikamet tezkeresine is tutuldugunun kaydettirilmesi yeni bir izin nitelił̧ini taşımamaktadır. Bu kayıt yabancının ulkedeki davranışlarını izleme olanağınu sağlayacak bir işlemdir. YISHK., m. 15 yabancıyı kontrol altında tutabilme amacına yönelmiştir": GÖGER, age., s.80.

35 "Umumiyetle mültecilerin ve iskan hakkındaki mevzuat dışında olarak yurt tutmak maksadjyla gelen yabancıların, pasaportları olsun olmasın Turkiye'ye kabulleri Içişleri Bakantığının kararına baģ lıdı"

36 Kars. TEKINALP, age., s.115-116, dn. 10. 
port Kanununun 8. maddesinin kapsamı dişında tutulması imkânının, ancak Türkiye'de iş tutmasıyla sağlanabileceğinin mümkün olabileceği hallerde, Türkiye'de tutacağı işin kanunların icabına uygunlưgunu önceden tespit etme ihtiyacı duyulmaktadır. Isste ön izin mahiyetindeki "çalışma vizesi" bu halde, pozitif hukukumuzda caiz göruilebilen bir belgedir.

Bu halin dışında ve hele Türkiye'ye pasaport ve vize işlemlerini usulüne uygun surette gerçekleştirerek giren yabancının Türkiye'de çalışmaya karar vermesi üzerine, mutlaka ülke dişına çıkarak "çalışma vizesi" alması yưküṃlülü̉güne tâbi kılınması suretinde gerçekleştirilen bir uygulama ${ }^{37}$ yalnız mevzuata ters düşmekle kalmaz, anlamsiz ve tuhaf bir tutum olarak kabul edilmek gerekir.

\section{V-Kanunî Rejim}

Diğer genel șartlar yerine getirilmiş bulunduğu takdirde, yabancıların çalışma hakkına ilişkin olarak, Türk kanunlarında öngörtilen sinırlamalarnn neler olduğu sorusunu yanitlamak üzere Türk (pozitif) hukukuna genel çerçevede baktığımızda başlıca şu hususlar tespit edilmektedir:

-Birtakım işler veya bazı çalışma alanları yabancılara (büsbütỉn) yasaklanmış buluṇmaktadır.

-Bazı işler veya birtakım faaliyet alanları (hizmet tirleri), şartlı olarak yabancılara açk tutulmaktadır; bu şartların arasında, izin şartının özellikle dikkat çektiği, daha seyrek hallerde ise, kontenjan şartlan veya diğer birtakım şartlann yer aldığg görülmektedir.

Buna rağmen, varsayımsal olarak pozitif hukukumuzun genel karakterini tespit etmek gerekirse, şöyle bir özet sunulabilir:

Kanunen sınır konmadığ ma hürriyetinden yararlanmasıdır. Bu nedenle de, kanunî sınırlamalann istisnaî oldugunun hatırlanması önem arz etmektedir. Dolaylsıyla, açık hüküm olarak ve dar yoruma tâbi surette kapsamı tayin edilerek tespit edilen kanunî sınırlamalar dışında yabancının çalışma hakkının varlığına ilişkin mülâhaza daima göz önünde tutulmalidur.

37 Doktrinde, çalısma vizesi alınmasını zorunlu olduğunu öne süren yazarlar bile, çalışma izni almadan Türkiye'ye gelip de sonradan çalışma olanał̧ bularak izin almak isteyen yabancilann yurt dișundaki bir Turk Konsoloshuğuna başvurmasının gerekli olmadığın, bunun gok ağır ve lözumsuz bir formalite oldưguno kabul etmektedirler: OKKÇUN, age., s. 105; TEKINALP, age., s.116-117; ÇELIKEL, age., s. 113. 